\title{
Peranan Ikatan Remaja Masjid Raya Sunur dalam Meningkatkan Kesadaran Beragama
}

\author{
Rezi Yuhanda Nasdi ${ }^{1}$, Indah Muliati ${ }^{2}$ \\ reziyuhandanasdi@gmail.com ${ }^{1}$, indahmuliati1979@gmail.com² \\ Universitas Negeri Padang ${ }^{1,2}$
}

\begin{tabular}{|c|c|}
\hline ARTICLE INFO & ABSTRACT \\
\hline Article history: & This research is motivated by an interest in the role of \\
\hline $\begin{array}{l}\text { Received, } 18 \text { Februari } \\
2022\end{array}$ & $\begin{array}{l}\text { mosque youth in increasing the religious awareness of } \\
\text { teenagers in Sunur Tengah. Nan Patient District, Padang }\end{array}$ \\
\hline $\begin{array}{l}\text { Revised, } 24 \text { Februari } \\
2022\end{array}$ & $\begin{array}{l}\text { Pariaman Regency. Because the youth of the Middle Sunur } \\
\text { Mosque has played a role and provided a positive influence, it } \\
\text { is evident from the teenagers of Central Sunur who diligently }\end{array}$ \\
\hline $\begin{array}{l}\text { Accepted, } 28 \text { Februari } \\
2022\end{array}$ & $\begin{array}{l}\text { pray in congregation at the mosque, the teenagers are diligent } \\
\text { in attending weekly wirid studies, guiding children to recite }\end{array}$ \\
\hline Keywords: & $\begin{array}{l}\text { the dawn education and a sense of caring and polite attitude } \\
\text { with the surrounding community. This studv aims to examine. }\end{array}$ \\
\hline Peranan, Remaja & first, to describe how the mosque's Youth Program increases \\
\hline Meningkatkan, & the religious awareness of teenagers in Sunur Tengah, and \\
\hline Keagamaan Islam & $\begin{array}{l}\text { awareness of religious youth in Sunur Tengah. The third is to } \\
\text { describe the sunporting factors and inhibiting factors for the }\end{array}$ \\
\hline Clonflict of Interest: & mosque youth program. This research is a type of field \\
\hline None & research using qualitative methods. The results showed that \\
\hline Funding: & $\begin{array}{l}\text { the mosque's youth program, (1) Tadarus tahsin Alquran, (2) } \\
\text { weekly wirid studies, (3) taught TPA children at dawn, and (4) }\end{array}$ \\
\hline None & $\begin{array}{l}\text { cadre of mosque youth by implementing the mosque youth } \\
\text { program. }\end{array}$ \\
\hline
\end{tabular}

Corresponding Author: Rezi Yuhanda Nasdi, Department Islamic Education Faculty of Social Science Universitas Negeri Padang, Indonesia, Email: reziyuhandanasdi@gmail.com, Phone No.: +6289630763540

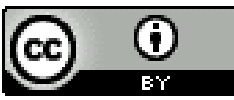

Copyright $(2022$, Author(s)

\section{Pendahuluan}

Peranan menurut terminologi adalah seperangkat tingkah yang diharapkan dimiliki oleh yang berkedudukan di masyarakat. Dalam bahasa Inggris peranan disebut "role" yang definisinya adalah "person"s task or duty in undertaking." Artinya tugas atau kewajiban seseorang dalam suatu usaha atau pekerjaan. Peran diartikan sebagai perangkat tingkah yang diharapkan dimiliki oleh orang yang berkedudukan dalam masyarakat. Sedangkan peranan merupakan tindakan yang dilakukan oleh seorang dalam suatu peristiwa.

Masjid merupakan tempat ibadah umat muslim, dan masjid sangat tepat digunakan sebagai sarana dakwah untuk para remaja muslim karena dengan berfungsinya masjid 
sebagai sarana dakwah remaja, maka pada dasarnya menjadikan penerus yang akan memakmurkan masjid di masa yang akan datang. Masjid sangat penting dalam struktur masyarakat Islam. Masjid bagi umat Islam memiliki makna yang besar dalam kehidupan, baik makna fisik maupun makna spiritual. Kata masjid itu sendiri berasal dari kata sajada-yasjudu-masjidan yang memili arti (tempat sujud). (Sofyan Syafri Harahap 1996: 26).

Remaja masjid adalah organisasi yang menghimpun remaja muslim yang aktif datang dan beribadah shalat berjama'ah di masjid. Karena keterikatannya dengan masjid, maka peran utamanya tidak lain adalah memakmurkan masjid. Ini berarti, kegiatan yang berorientasi pada masjid selalu menjadi program utama. Didalam melaksanakan peranannya, remaja masjid meletakkan prioritas pada kegiatankegiatan peningkatan keislaman, keilmuan dan keterampilan anggotanya (Zulmaron et al., 2017b: 41).

Kesadaran beragama berasal dari kata dasar "sadar" dan "agama". Kata "sadar" mempunyai arti; insaf, yakin, merasa, tahu dan mengerti. Kesadaran berarti; keadaan tahu, mengerti dan merasa ataupun keinsafan. (Departemen Pendidikan Nasional, 2008: 1198). Kesadaran beragama diartikan sebagian atau segi yang hadir dalam pikiran dan dapat diuji melalui intropeksi. Dengan kata lain, kesadaran beragama merupakan aspek mental dan aktifitas keagamaan (beragama) seseorang. (Ramayulis, Psikologi Agama, Jakarta: Kalam Mulia 2002:7).

Dapat disimpulkan, peranan merupakan tindakan atau prilaku yang dilakukan oleh seorang atau kelompok dalam suatu peristiwa. Kesadaran beragama adalah keadaan tahu akan diri dan mengerti terhadap penciptanya untuk apa Allah menciptakan manusia ialah untuk beribadah kepada Allah dan menjadi khalifah di dunia ini sehingga keberadaan Tuhannya tercipta di dalam dirinya yang dengan keadan tersebut ia melaksanakan segala perintah Sang Kholik Allah SWT dan menjauhi larangan-Nya Serta meningkatkan Ketaqwaan Kepada Allah tanpa adanya unsur keterpaksaan.

Setelah peneliti melakukan obserasi di Sunur Tengah kecamatan nan sabaris kabupaten padang pariaman pada tanggal 10 januari 2022, sebelum adanya kegiatan remaja masjid di temukan banyak remaja yang tidak sholat berjamaah di masjid, tidak menghadiri kajian wirid mingguan, kurangnya rasa kepedulian pada acara keagamaan di lingkungan sekitar, kurangnya kualitas membaca Alquran pada remaja. Perilaku remaja yang tidak sesuai dengan ajaran agama islam seperti bermain game online di warnet sampai subuh, keluyuran menonton orgen tunggal, berpacaran dan berboncengan kumpul-kumpul tak jelas laki-laki dan perempuan, merokok sedangkan masih SD dan SMP. Kondisi remaja masih banyak yang tidak sholat berjamaah ke masjid dan sedikit remaja menghadiri kajian mingguan dan kurangnya rasa kepedulian pada acara keagamaan di Sunur Tengah. Kondisi remaja yang masih banyak melakukan penyimpangan di sebabkan karna kurangnya ilmu agama, malas belajar, malas menghadiri kajian wirid mingguan di pengaruhi teman sepergaulan dan rendahnya kesadaran remja sebagai seorng muslim. Hal itu disebabkan karna mereka belum mengamalkan ajaran agama secara baik.

Melihat kondisi remaja yang meresahkan tersebut akhirnya terbentuklah ikatan remaja masjid raya sunur pada tanggal 28 oktober 2018 yang di perkarsai oleh Pak yudistian dores S.Pd untuk meningkatkan kesadaran beragama remaja di Sunur Tengah. Adapun kegiatan remaja masjid yang di lakukan terhadap remaja yaitu dengan 
mengadakan kegiatan positif seperti, tadarus tahsin Alquran, kajian wirid mingguan, membimbing anak-anak TPA didikan subuh, pengkaderan remaja masjid, dan kegiatan olahraga Bulu tangkis.

Berdasarkan observasi yang dilakukan di Masjid Raya Sunur Tengah pada tanggal 23 sampai 31 Januari penulis telah melakukan wawancara bersama Pembina remaja masjid, pengurus remaja masjid, Tokoh masyarakat, orang tua remaja masjid dan anggota remaja masjid Sunur Tengah. Peneliti menemukan pernyataan dari beberapa narasumber yang berkaitan dengan remaja masjid mereka mengtakan bahwasanya semenjak adanya remaja masjid ini menjadikan remaja yang ikut bergabung pada remaja masjid memiliki kesadaran beragama yang mana sebelum adanya organisasi remaja masjid ini remaja jarang sholat berjamaah ke masjid, sedikit yang hadir pada saat wirid mingguan, dan kurang pedulinya pada kegiatan keagamaan yang di adakan di Sunur Tengah. Sehingga menyebabkan pengurus remaja masjid berinisiatif dan berupaya untuk membuat organisasi remaja masjid yang mana tujuan utamanya adalah untuk mengajak dan merangkul remaja masjid dalam ikatan remaja masjid Sunur Tengah. pada tanggal 28 oktober 2018 di bentuklah ikatan remaja masjid Sunur Tengah yang di resmikan oleh wali nagari sunur yaitu bapak. H. Hafrizal B.sc.

Setelah peresmian di tunjuk dan di tetapkanlah ketua dan jajaran dari remaja masjid setelah di bentuknya kepengurusan maka di rancanglah program remaja masjid yang mana program ini bertujuan untuk meningkatkan kesadaran beragama di Sunur Tengah adapun program remaja masjid di antaranya: tadarus dan tahsin Alquran di bimbing oleh guru mengaji, pengajian rutin wirid mingguan wajib bagi semua anggota remaja masjid, kajian bulanan yang diadakan khusus untuk remaja masjid, empat didikan subuh membimbing dan mengajarkan anak-anak TPA pada saat pelaksanaan didikan subuh setelah didikan subuh selesai remaja masjid mengadakan sarapan bersama dan dilanjutkan dengaan goro membersihkan lingkungan msjid, lima menghadiri acara ta'ziah di rumah ahlul bait, enam mengadakan latihan bulu tangkis di lingkungan masjid. Dengan program dan usaha dari pengurus remaja masjid Alhamdulillah menjadikan remaja masjid Sunur Tengah berubah lebih baik pada segi agama serta kepedulian dan sopan santun pada masyarakat sekitar.

\section{Tinjauan Pustaka}

Dalam Kamus Besar Bahasa Indonesia, peranan adalah bagian dari tugas utama yang harus dilaksanakan (Jakarta: Balai Pustaka 1998: 667). Bagian yang dimainkan seorang pemain dan tindakan yang dilakukan oleh seseorang dalam suatu peristiwa. yang dimaksud dengan peranan merupakan kewajiban-kewajiban dan menjadi sebuah keharusan yang dilakukan seseorang karena kedudukannya di dalam status tertentu dalam suatu masyarakat atau lingkungan dimana ia berada. Peranan adalah suatu kompleks pengharapan manusia terhadap caranya individu harus bersikap dan berbuat dalam situasi tertentu berdasarkan status dan fungsi sosialnyaDalam masalah peranan sering dibedakan dalam peranan sosial dan peranan individual. Peranan diartikan sebagai perangkat tingkah yang diharapkan dimiliki oleh orang yang berkedudukan dimasyarakat. Kedudukan dalam hal ini diharapkan sebagai posisi tertentu di dalam masyarakat yang mungkin tinggi. Sedang-sedang saja atau rendah. Kedudukan adalah suatu wadah yang isinya adalah hak dan kewajiban tertentu. sedangkan hak dan kewajiban tersebut dapat dikatakan sebagai peran. oleh karena itu, maka seseorang yang mempunyai kedudukan tertentu dapat dikatakan sebagai 
pemegang peran (role accupant). Suatu hak sebenarnya merupakan wewenang untuk berbuat atau tidak berbuat, sedangkan kewajiban adalah beban atau tugas.

Remaja menurut Kamus Besar Bahasa Indonesia adalah etape usia mulai dewasa; sudah sampai umur untuk kawin. Syamsul Yusuf LN mengemukakan pengertian tentang remaja yaitu remaja merupakan segmen perkembangan individu yang sangat penting, yang diawali dengan matangnya organ-organ fisik (seksual) sehingga mampu berreproduksi (Syamsu Yusuf, 2011:184).

Dapat disimpulkan peranan adalah aspek dinamis yang berupa tindakan atau perilaku yang dilaksanakan oleh seseorang yang menempati atau memangku suatu posisi dan melaksanakan hak-hak dan kewajiban sesuaian dengan kedudukannya dan kesadaran beragama adalah keadaan diri seseorang yang paham akan tujuan penciptaannya di dunia ini dengan niat yang ada di dalam hati kemudian di praktekkan dengan sikap yang muncul dalam diri sendiri untuk melakukan tindakan serta berproses dari keadaan diri yang kurang peka dan kurang giat dalam hal kebaikan menuju perubahan diri yang lebih baik dengan senantiasa introspeksi diri dan melakukan kegiatan serta arahan dari syariat Agama

Ikatan Remaja masjid merupakan suatu sarana untuk mempererat tali silaturahim sesama anggota remaja baik dalam pergaulan sesama remaja maupun pergaulan dalam masyarakat sekitar Ikatan remaja masjid berfungsi sebagai tempat latihan para remaja dalam rangka mengembangkan dan mempersiapkan diri, agar menjadi seorang muslim dan warga Negara Indonesia berdasarkan pancasila yang berkualitas. Adapun fungsi utama remaja masjid yaitu memakmurkan masjid, kaderisasi ummat, dakwah dan sosial masyarakat.

Adapun tujuan remaja masjid adalah Membina generasi remaja muslim agar menjadi kader penerus perjuangan agama, bangsa, dan negara yang bertaqwa kepada Allah SWT, memiliki ilmu pengetahuan dan berwawasan luas dan Senantiasa memakmurkan masjid dengan mengadakan kegiatan-kegiatan yang berpegang teguh kepada prinsip-prinsip agama islam. Allah Subhanahu Wa Ta'ala berfirman:

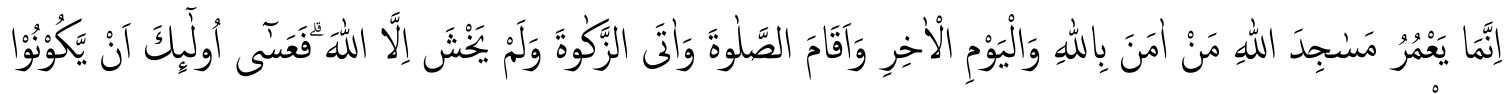
مِنَ الْمُهْتَدِيْنَ

Artinya:

"Sesungguhnya yang memakmurkan masjid Allah hanyalah orang-orang yang beriman kepada Allah dan hari kemudian, serta (tetap) melaksanakan sholat, menunaikan zakat, dan tidak takut (kepada apa pun) kecuali kepada Allah. Maka mudah-mudahan mereka termasuk orang-orang yang mendapat petunjuk." (QS. At-Taubah 9: Ayat 18).

Visi dari Ikatan remaja masjid Sunur Tengah yaitu Organisasi yang berorientasi pada peranan pembentukan akhlak yang baik dengan akidah yang benar dan meningkatkan Kesadaran beragama, bersosial yang menerapkan nilai-nilai agama islam. Misi dari Irema ialah mengadakan dan melaksanakan kegiatan untuk meningkatkan kesadaran beragama. Kaderisasi terencana guna melanjutkan 
organisasi serta Menjalin dan membina hubungan silaturahim yang baik antar pengurus, anggota, pengurus masjid dan masyarakat sekitar.

\section{Metode}

Penelitian ini merupakan jenis penelitian lapangan (field research) dengan menggunakan metode kualitatif. Metode peneltian kualitatif adalah metode penelitian yang berlandaskan pada filsafat postpositivisme, digunakan untuk meneliti kondisi objek yang alamiah, (sebagai lawannya adalah eksperimen) di mana peneliti adalah sebagai instrument kunci pengambilan sampel sumber data dilakukan secara purposive dan teknikpengumpulan dengan trianggulasi (gabungan), analisis data bersifat induktif/kualitatif, dan hasil penelitian kualitatif lebih menekankan makna dari pada generilisasi (Sugiyono, 2014: 15).

\section{Hasil dan Pembahasan}

\section{Meningkatkan Kesadaran Remaja Masjid Sunur Tengah untuk Sholat Berjamaah ke Masjid}

Berdasarkan observasi pada tanggal 21 Januari 2022 peneliti menemukan remaja yang ikut dalam ikatan remaja masjid lebih rajin sholat berjama'ah ke masjid remaja masjid ada yang bertugas sebagai muadzin dan juga sebagai imam sholat sebagian remaja masid yang lain bertugas mengajarkan anak-anak tpa mengaji. Dalam program remaja masjid di adakannya pengajian wirid mingguan tiga kali seminggu di tempat yang berbeda malam selasa di surau galanggang atau masjid raya sunur, malam kamis di surau Al-manar dan malam Jum'at di surau Kampung Aur dalam kajian wirid mingguan banyak ilmu yang di sampaikan oleh ustad akan keutamaan dan pentingnya menjaga sholat dan sholat berjamaah di masjid. remaja masjid di wajibkan hadir pada saat kajian mingguan di harapkan dapat membekali remaja masjid ilmu agama dan bisa memakmurkan masjid. kemudian yang peneliti temukan adalah remaja mulai terbiasa mengucapkan salam saat masuk dan keluar rumah.

Dari hasil wawancancara dan observasi dengan pemuka, pembina, dan masyarakat dapat disimpulkan bahwa. Pak Romi menyampaikan peranan remaja masjid terlihat saat remaja mulai rajin sholat berjama'ah ke masjid, saling bertegur sapa dan sopan dengan orang yang lebih tua. Disini remaja masjid berperan sebagai pengingat dan pengajar bagi remaja agar remaja dan masyrakat lebih ta'at akan perintah Allah dan hidup bersosial lebih rukun.

\section{Meningkatkan Kesadaran Remaja dalam Memakmurkan Masjid}

Berdasarkan observasi pada malam tanggal 22 Januari 2022 ditemukan bahwa remaja masjid menghadiri kajian wirid mingguan pada saat jadwal kajian malam selasa di surau galanggang remaja datang sebelum sholat isya dan sholat isya berjamaah namun ada juga sebagian remaja yang terlambat datang di karnakan ada kesibukan kuliah dan juga yang terlambat karna ngajar di sekolah. Berdasarkan obserasi peneliti dari hari-hari sebelumnya dapat di lihat yang hadir pada saat kajian mingguan adalah bapak-bapak dan ibuk-ibuk adapun remaja nya sibuk dengan bermain game online, pada saat itu remaja bermain game online di warnet bahkan mereka sanggup bergadang sampai subuh untuk bermain game online kemudian mereka bermain game online di hp, peneliti menemukan banyak orang tua remaja yang mengeluh akan keadaan anaknya yang kecanduan game online dan kurang pandai memenfaatkan waktunya. Dan juga remaja sebelum adanya remaja masjid mereka sering begadang 
menonton game online sembari merokok padahal mereka baru kelas enam SD sampai kelas dua SMA tapi gayanya merokok sudah seperti orang dewasa bahkan banyak diantara mereka yang membeli rokok dengan uang orang tua nya tentulah ini menjadi PR besar bagi remaja masjid untuk merangkul remaja Sunur Tengah dan mengajak nya untuk bergabung.

Setelah dilakukan pendekatan dengan remaja baik itu secara langsung maupun ajakan melalui media sosial perlahan mereka mau ikut bergabung dengan ikatan remaja masjid dan untuk memberikan tanggung jawab pada mereka pengurus remaja masjid memberikan jabatan kepada remaja dan remaja di bimbing dan di bantu dalam menjalankan tugasnya sebagai anggota dan pengurus remaja masjid. Setelah beberapa bulan berjalan remaja masjid mulai aktif mengikuti program remaja masjid dan dengan begitu perubahan dapat di lihat yaitu remaja mulai dan sudah sholat berjamaah ke masjid dan memakmurkan masjid.

Dari hasil wawancara dan observasi dapat disimpulkan bahwa remaja masjid berperan bagi remaja Sunur Tengah menambah pengetahuan dan ilmu mereka tentang ilmu agama agar remaja dapat melaksanakan kewajibannya sebagai muslim yakni menjadikan remaja masjid sholat berjamaah ke masjid dan memakmurkan masjid yang mana itu di dapatkan pada saat mengikuti program remaja masjid.

\section{Menjadikan Remaja Sunur Tengah Aktif dan Peduli pada Acara Keagamaan}

Berasarkan observasi pada tanggal 31 Januari 2022 pukul 21.35 di temukan bahwa remaja masjid ikut merapikan dan mengembangkan tikar untuk tadarus Alquran, mejembut air mineral untuk anggota remaja masjid yang ikut pada saat tadarus Alquran baik yang dilakukan di tempat takziah di rumah duka maupun pada saat tadarus dan tahsin pada program remaja masjid dan juga mereka memilih sampah yang ada di perkarangan masjid. Dan pada saat bulan ramadhan tahun kemarin remaja masjid bertugas sebagai protokol ceramah, membaca Alquran. Kemudian pada saat takziah remaja masjid juga ikut memasang tenda untuk acara takziah malamnya kemudian ikut menggali kuburan dan itu dilakukan bergantian. Hal ini dilakukan remaja masjid salah satunya karna arahan dari pengurus remaja masjid agar membantu pengurus masjid dalam melaksanakan acara keagamaan di lingkungan sekitar.

Dari hasil wawancara dan observasi di atas dapat penulis simpulkan bahwa remaja masjid Sunur Tengah berperan dalam syiar agama yaitu berdakwah mengajak remaja lainnya untuk mengikuti kegiatan remaja masjid dan membangkitkan rasa kepedulian antar sesama anggota remaja masjid dan menghormati masyarakat sekitar seperti mengucapkan salam pada orang tua dan jamaah dan ikut serta membantu saat ada acara seperti takziah, acara pemuda dan acara pernikahan.

\section{Menjadikan Remaja Sunur Tengah Fasih dan Benar dalam Membaca Alquran}

Berdasarkan observasi penulis pada tanggal 21 Januari pukul 20.30. saat pelaksanaan program remaja masjid tadarus Alquran mengaji bersama penulis menemukan bahwasanya remaja masjid masih ada yang kurang lancar dalam membaca Alquran dan masih banyak yang salah makhraj dan mad nya kemudian di benarkan oleh ustadz romi selaku guru mengaji. Tahsin atau memperbaiki bacaan qur'an. Jadwal tadarusan ini dilaksanakan setiap malam senin di Masjid raya sunur Rangkaian kegiatannya yaitu Sholat maghrib dan isya berjamaah kemudian berkumpul 
membentuk lingkaran setelah itu berdoa sebelum pengajian dimulai Kemudian menuliskan daftar hadir setiap anggota dilakukan bergiliran Dengan buku absen. Kemudian dimulailah pembacaan Alquran sepuluh ayat tiap-tiap anggota. Dibimbing oleh Guru Mengaji yaitu pak Romi.

Dari hasil wawancara dan observasi diatas dapat di simpulkan bahwa program remaja masjid mengaji bersama secara bergiliran satu persatu bagus untuk remaja agar pandai dan fasih dalam membaca Alquran dan juga di bimbing oleh guru mengaji dan juga di dengarkan oleh semua anggota remaja masjid jadi semua saling mendengarkan dan saling menunjukkan jika ada yang salah.

\section{A. Remaja masjid berperan dalam acara didikan subuh dengan ikut mengajarkan anak-anak mengaji TPA dan mensukseskan acara didikan subuh.}

Berdasarkan observasi subuh tanggal 30 januari 2022 peneliti menemukan di lapangan pada saat kegiatan didikan subuh remaja masjid ikut dalam acara didikan subuh dengan mengajarkan anak-anak TPA melaksanakan tugasnya sebagai pelaksana didikan. remaja masjid santusias dalam memebersamai anak-anak TPA didikan subuh setelah acara didikan subuh selesai remaja masjid dan anak-anak TPA di arahkan untuk goro bersama membersihkan lingungan masjid dan surau, saat goro di bagi dua perempuan di tugaskan membersihkan bagian dalam masjid dan surau sedangkan lakilaki ditugaskan membersihkan perkarangan masjid dan wc. Goro dilaksanakan sampai jam 10-11 pagi dan setelah goro remaja dan anak-anak mengaji di berikan sarapan sebelum pulang kerumah masing-masing.

Dari hasil wawancara dan observasi dapat disimpulkan bahwa didikan subuh sangat bermanfaat bagi remaja masjid dan menjadikan anak-anak mengaji TPA dapat latihan berbicara didepan orang banyak dan menambah ilmu pengetahuan nya tentang agama setiap pelaksana didikan subuh diberikan tugas seperti protokol, pembacaan Alquran, sari tilawah pembacaan ayat pendek dan tambahan pelajaran atau kultum oleh ustadz. Jadi manfaat didikan subuh adalah ilmu agama bertambah dan salin menjalin hubungan silaturahim antar sesama.

\section{Menjadikan Remaja Sunur Tengah Paham Ilmu Agama dengan Pengajian Wirid Mingguan}

Berdasarkan observasi pada malam hari tanggal 22 Januari 2022 saat wirid mingguan remaja masjid mengikuti dan mendengarkan penyampaian ustadz, kemudian remaja masjid bertugas sebagai muadzin, protokol, pembacaan ayat suci Alquran dan pembacaan sari tilawah. Semua anggota di wajibkan hadir bagi anggota remaja masjid yang tidak hadir tanpa alasan yang benar kami bersepakat di kenakan sanksi berupa infak untuk kas Remaja masjid. Kajian Mingguan bertujuan untuk membekali remaja masjid tentang dasar-dasar agama Islam seperti apa itu Iman, Islam, akhlak, dan lain-lain. Ini di buktikan wawancara dengan pak Yudi tanggal 23 Januari 2022.

Dari hasil wawancara dan observasi dapat disimpulkan bahwa kajian wirid mingguan sangat bermanfaat bagi remaja masjid dan juga untuk masyarakat Sunur Tengah dengan menghadiri wirid mingguan remaja masjid dapat sholat berjamaah ke masjid khususnya sholat Maghrib dan isya dan juga menjadikan wirid mingguan sebagai momen berkumpul dan membahas program remaja masjid. 
Rezi Yuhanda Nasdi dan Indah Muliati : Peranan Ikatan Remaja Masjid Raya Sunur....

\section{Faktor Pendukung Peranan Remaja Masjid dalam Meningkatkan Kesadaran Beragama}

Berdasarkan hasil wawancara dengan Pembina Irema pada tanggal 24 Januari 2022. Pukul: 21.40 WIB. Menurut Pak Yudi:

"Faktor Pendukung Ikatan Remaja Masjid yang disingkat dengan Irema yaitu faktor internal antara lain yaitu dari dalam seperti orang tua ada juga yang memaksakan anaknya untuk selalu berkontribusi atau menghadiri acara-acara wirid mingguan dan belajar Alquran di surau, kemudian faktor internal lainnya dorongan dan kesadaran dari dalam dirinya sendiri, ada juga yang sering adzan di masjid dan mengaji di masjid dan ada juga yg sering ke masjid memakmurkan masjid saat sholat berjamaah. Kemudian faktor Eksternal dari luar, Untuk faktor eksternal nya antara lain yang pertama seperti dukungan dari pengurus dengan memberikan uang atau hadiah bagi yang sering mengaji dan sering adzan di masjid itu yang membuat remaja semangat memakmurkan masjid, kemudian ajakan dari teman-teman sebaya".

Dan Berdasarkan observasi yang penulis lakukan pada tanggal 22 Januari 2022. Adapun faktor pendukung yang penulis temukan yaitu: Lokasi lapangan Bulu Tangkis berada di Sebelah Masjid Raya sunur itu yang menyebabkan remaja yang olahraga bulu tangkis Bergegas ke masjid dan apabila waktu sholat masuk mereka bergegas sholat berjamaah Surau Galanggang yang dekat dengan masjid menyebabkan remaja mudah dalam menghadiri kegiatan remaja masjid. Adapun faktor pendukung lainnya yaitu semangat dari remaja dan ajakan dari pengurus Irema untuk memakmurkan masjid serta adanya dukungan dari orang tua dari remaja.

\section{Faktor Penghambat Peranan Remaja Masjid dalam Meningkatkan Kesadaran Beragama}

Berdasarkan wawancara dan observasi yang peneliti lakukan pada tanggal 22 januari 2022. Kesibukan masing-masing dari tiap Pengurus seperti kuliah, ngajar dan keperluan pekerjaan. Untuk mengetahui kebenaran dari faktor penghambat mengenai Kesibukan anggota Pengurus seperti kuliah dan kesibukan pekerjaan. Dan dari hasil wawancara dan observasi diatas dapat di simpulkan faktor penghambat peranan remaja masjid adalah ada beberapa orang tua yang kurang paham ilmu agama sehingga kurangnya peran orang tua untuk menyuruh anaknya mengikuti remaja masjid dan juga di sebabkan kesibukan masing-masing seperti kuliah, ngajar dan keperluan yang mendadak lainnya.

Solusi Pembina Irema dalam mengatasi faktor penghambat dari peranan Irema Dalam meningkatkan kesadaran beragama di Sunur Tengah kabupaten Padang Pariaman adalah yaitu kurangya Bantuan dana dari perangkat Nagari. Pengurus Remaja masjid semangat mengajak remaja, orang tua remaja dan masyarakat sekitar. Untuk mengatasi masalah kurangnya bantuan dari perangkat Nagari dapat ditemukan dalam kutipan wawancara dengan Pembina Irema pada tanggal 26 Januari 2022 Pukul: 23.19 WIB. Menurut Yusril Eza Mahendra S. Pd:

"Menurut yusril, yang pertama harus ada komitmen yang dibangun antar seluruh pengurus, pembina dan masyarakat. Komitmen dan niat tu harus dibangun sedini mungkin. Kemudian harus ada dukungan dari pembina dan perangkat Nagari setempat baik dukungan berupa moril dan materiil, karena seringkali pembina dan pemerintah desa lepas tangan. Diawali kepengurusan, seluruh anggota harus dibekali dengan semangat, nilai-nilai kepemimpinan, agama, dan organisasi. Dan setelahmya perlu ada 
kaderisasi, agar kepengurusan remaja masjid bersifat kontinuitas, tidak terhenti pada satu generasi"

Dari hasil wawancara dan observasi diatas dapat disimpulkan bahwa pendanaan untuk remaja masjid dapat diperoleh dari donatur dan tokoh masyarakat yaitu dengan mengajukan proposal kepada wali nagari untuk kegiatan remaja masjid dan juga bantuan dari masyarakat dan orang perantauan.

\section{Simpulan}

Berdasarkan hasil penelitian tentang peranan remaja masjid raya sunur dalam meningkatkan kesadaran beragama di Sunur Tengah diketahui bahwa: sebelum adanya ikatan remaja masjid remaja Sunur Tengah kurang perhatiannya untuk sholat berjamaah ke masjid, kurang efektif memanfaatkan waktu sering main game online di warnet bahkan sampai subuh, keluyuran menonton orgen tunggal sehingga bolos sekolah. Melihat kondisi tersebut pengurus remaja remaja masjid berinisiatif untuk membentuk ikatan remaja masjidyang mana. Tujuan dari program dan kegiatan remaja masjid Sunur Tengah adalah untuk meningkatkan kesadaran beragama pada remaja Sunur Tengah. Menjadikan remaja Sunur Tengah rajin sholat berjamaah ke masjid, meningkatkan kesadaran beragama remaja untuk memakmurkan masjid, Menjadikan remaja Sunur Tengah aktif dan peduli pada acara keagamaan, menjadikan remaja Sunur Tengah fasih dan benar dalam membaca Alquran dan remaja masjid membimbing serta mengajarkan anak-anak TPA didikan subuh. Adapun faktor pendukung di antaranya latar belakang anggota, dan semangat pengurusdan anggota remaja masjid. Faktor penghambat dimantaranya kesibukan sebagian pengurus, seperti kuliah dan mengajar.

\section{Referensi}

Abdullah, Supriyanto. Masjid: Peran dan Fungsi. (Yogyakarta: Cahaya Hikmah, 2003)

Al-Qaradhawi, Yusuf. Tuntunan Membangun Masjid, Al-Shirat AlSyar'iyah li Bina AlMasajid, (Jakarta: Gema Insani Press, 2000)

Departemen Pendidikan dan Kebudayaan RI., Kamus Besar Bahasa Indonesia, (Jakarta:Balai Pustaka, 2010), h. 377

Departemen Pendidikan dan Kebudayaan, Kamus Besar Bahasa Indonesia, (Jakarta : Balai Pustaka 1998), h.667

Munir dan Wahyu Illaihi, Manajemen Dakwah, (Jakarta: Kencana, 2009)

Mustofa, Budiman. Manajemen Masjid Gerakan Meraih Kembali Kekuatan Masjid dan Potensi Masjid. (Solo: Ziyad Visi Media, 2007)

Mutia, S. P. T. (2014). Pengaruh sanksi perpajakan, kesadaran perpajakan, pelayanan fiskus, dan tingkat pemahaman terhadap kepatuhan wajib pajak orang pribadi (Studi Empiris pada Wajib Pajak Orang Pribadi yang terdaftar di KPP Pratama Padang. Artikel Ilmiah, 2(1), 2-29.

Rifa'i, A. Bachrun dan Moch. Fakhruroji. Manajemen Masjid: Mengoptimalkan Fungsi Sosial Ekonomi Masjid. (Bandung: Benang Merah Press, 2005)

Rukmana D.W. Nana. Masjid dan Dakwah. (Jakarta: Al Mawardi Prima, 2002)

R. Sutyo Bakir, Kamus Lengkap Bahasa Indonesia, Tanggerang: Karisma Publishing 
Rezi Yuhanda Nasdi dan Indah Muliati : Peranan Ikatan Remaja Masjid Raya Sunur....

Group, 2009, hlm.348

Sofyan Syafri Harahap, Manajemen Masjid, (Jogyakarta: Bhakti Prima Rasa, 1996), h. 26

Subagyo, M. Metode Penelitian dalam Teori dan Praktek. (Jakarta: Bumi Aksara, 1991)

Syafaat, Habib. Buku Pedoman Dakwah, (Jakarta: Penerbit Widjaya, 1982)

Sugiyono. (2014). Metode penelitian pendidikan pendekatan kualitatif, kuantitatif Dan $R \& D$. Bandung: Alfabeta.

WJS Purwa Darminta, Kamus umum Bahasa Indonesia, (Jakarta: Balai Pustaka, 1996), hlm. 1030

Zulmaron, Z., Noupal, M., \& Aliyah, S. (2017a). Peran Sosial Keagamaan Remaja Masjid Di Kelurahan Pipa Reja Kecamatan Kemuning Palembang. Jurnal Studi Agama, 1(1), 41-54. https://doi.org/10.19109/JSA.V1I1.1546 